\title{
AEROMAGNETIC MAP OF CENTRAL PINE COUNTY, MINNESOTA AND ADJACENT PARTS OF WISCONSIN
}

\author{
GEOPHYSICAL INVESTIGATIONS \\ MAP GP-636
}

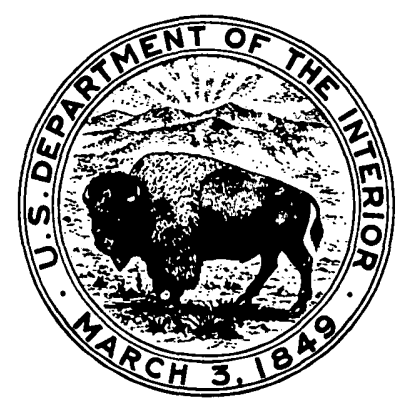

